\section{Military Technical College Kobry El-Kobbah, Cairo, Egypt}

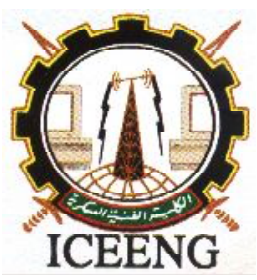

\section{$10^{\text {th }}$ International Conference on Electrical Engineering ICEENG 2016}

\title{
Clean Energies Development and Sustainable Development
}

\section{Introduction}

Over millions of years ago, plants have covered the earth converting the energy of sunlight into living plants and animals, some of which was buried in the depths of the earth to produce deposits of coal, oil and natural gas [1-3]. The past few decades, however, have experienced many valuable uses for these complex chemical substances and manufacturing from them plastics, textiles, fertiliser and the various end products of the petrochemical industry. Indeed, each decade sees increasing uses for these products. Coal, oil and gas, which will certainly be of great value to future generations, as they are to ours, are however non-renewable natural resources. The rapid depletion of these non-renewable fossil resources need not continue. This is particularly true now as it is, or soon will be, technically and economically feasible to supply all of man's needs from the most abundant energy source of all, the sun. The sunlight is not only inexhaustible, but, moreover, it is the only energy source, which is completely non-polluting [4].

Industry's use of fossil fuels has been largely blamed for warming the climate. When coal, gas and oil are burnt, they release harmful gases, which trap heat in the atmosphere and cause global warming. However, there had been an ongoing debate on this subject, as scientists have struggled to distinguish between changes, which are human induced, and those, which could be put down to natural climate variability. Notably, human activities that emit carbon dioxide $\left(\mathrm{CO}_{2}\right)$, the most significant contributor to potential climate change, occur primarily from fossil fuel production. Consequently, efforts to control $\mathrm{CO}_{2}$ emissions could have serious, negative consequences for economic growth, employment, investment, trade and the standard of living of individuals everywhere.

\section{Energy sources and use}

Scientifically, it is difficult to predict the relationship between global temperature and greenhouse gas (GHG) concentrations. The climate system contains many processes that will change if warming occurs. Critical processes include heat transfer by winds and tides, the hydrological cycle involving evaporation, precipitation, runoff and groundwater and the formation of clouds, snow, and ice, all of which display enormous natural variability. The equipment and infrastructure for energy supply and use are designed with long lifetimes, and the premature turnover of capital stock involves significant costs. Economic benefits occur if capital stock is replaced with more efficient equipment in step with 
its normal replacement cycle. Likewise, if opportunities to reduce future emissions are taken in a timely manner, they should be less costly. Such a flexible approach would allow society to take account of evolving scientific and technological knowledge, while gaining experience in designing policies to address climate change [4].

The World Summit on Sustainable Development in Johannesburg in 2002 [4] committed itself to "encourage and promote the development of renewable energy sources to accelerate the shift towards sustainable consumption and production". Accordingly, it aimed at breaking the link between resource use and productivity. This can be achieved by the following:

- Trying to ensure economic growth does not cause environmental pollution.

- Improving resource efficiency.

- Examining the whole life-cycle of a product.

- Enabling consumers to receive more information on products and services.

- Examining how taxes, voluntary agreements, subsidies, regulation and information campaigns, can best stimulate innovation and investment to provide cleaner technology.

The energy conservation scenarios include rational use of energy policies in all economy sectors and the use of combined heat and power systems, which are able to add to energy savings from the autonomous power plants. Electricity from renewable energy sources is by definition the environmental green product. Hence, a renewable energy certificate system, as recommended by the World Summit, is an essential basis for all policy systems, independent of the renewable energy support scheme. It is, therefore, important that all parties involved support the renewable energy certificate system in place if it is to work as planned. Moreover, existing renewable energy technologies (RETs) could play a significant mitigating role, but the economic and political climate will have to change first. It is now universally accepted that climate change is real. It is happening now, and GHGs produced by human activities are significantly contributing to it. The predicted global temperature increase of between 1.5 and $4.5^{\circ} \mathrm{C}$ could lead to potentially catastrophic environmental impacts [5]. These include sea level rise, increased frequency of extreme weather events, floods, droughts, disease migration from various places and possible stalling of the Gulf Stream. This has led scientists to argue that climate change issues are not ones that politicians can afford to ignore, and policy makers tend to agree [5]. However, reaching international agreements on climate change policies is no trivial task as the difficulty in ratifying the Kyoto Protocol and reaching agreement at Copenhagen have proved.

Therefore, the use of renewable energy sources and the rational use of energy, in general, are the fundamental inputs for any responsible energy policy. However, the energy sector is encountering difficulties because increased production and consumption levels entail higher levels of pollution and eventually climate change, with possibly disastrous consequences. At the same time, it is important to secure energy at an acceptable cost in order to avoid negative impacts on economic growth. To date, renewable energy contributes only as much as $20 \%$ of the global energy supplies worldwide [5]. Over two thirds of this comes from biomass use, mostly in developing countries, and some of this is unsustainable. However, the potential for energy from sustainable technologies is huge. On the technological side, renewables have an obvious role to play. In general, there is no problem in terms of the technical potential of renewables to deliver energy. Moreover, there are very good opportunities for RETs to play an important role in reducing emissions of GHGs into the atmosphere, certainly far more than have been exploited so far. However, there are still some technical issues to address in order to cope with the intermittency of some renewables, particularly wind and solar. Nevertheless, the biggest problem with relying on renewables to deliver the necessary cuts in GHG emissions is more to do with politics and policy issues than with technical ones [6]. For example, the single most important step governments could take to promote and increase the use of renewables is to improve access for renewables to the energy market. This access to the market needs to be under favourable conditions and, possibly, under favourable economic rates as well. One move that could help, or at least justify, better market access would be to acknowledge that there are environmental costs associated with other 
energy supply options and that these costs are not currently internalised within the market price of electricity or fuels. This could make a significant difference, particularly if appropriate subsidies were applied to renewable energy in recognition of the environmental benefits it offers. Similarly, cutting energy consumption through end-use efficiency is absolutely essential. This suggests that issues of end-use consumption of energy will have to come into the discussion in the foreseeable future [7].

However, RETs have the benefit of being environmentally benign when developed in a sensitive and appropriate way with the full involvement of local communities. In addition, they are diverse, secure, locally based and abundant. In spite of the enormous potential and the multiple benefits, the contribution from renewable energy still lags behind the ambitious claims for it due to the initially high development costs, concerns about local impacts, lack of research funding and poor institutional and economic arrangements [8]. Hence, an approach is needed to integrate renewable energies in a way that meets the rising demand in a cost-effective way.

\section{Role of energy efficiency system}

The prospects for development in power engineering are, at present, closely related to ecological problems. Power engineering has harmful effects on the environment, as it discharges toxic gases into atmosphere and also oil-contaminated and saline waters into rivers, as well as polluting the soil with ash and slag and having adverse effects on living things on account of electromagnetic fields and so on. Thus there is an urgent need for new approaches to provide an ecologically safe strategy. Substantial economic and ecological effects for thermal power projects (TPPs) can be achieved by improvement, upgrading the efficiency of the existing equipment, reduction of electricity loss, saving of fuel, and optimisation of its operating conditions and service life leading to improved access for rural and urban low-income areas in developing countries through energy efficiency and renewable energies.

Sustainable energy is a prerequisite for development. Energy-based living standards in developing countries, however, are clearly below standards in developed countries. Low levels of access to affordable and environmentally sound energy in both rural and urban low-income areas are therefore a predominant issue in developing countries. In recent years many programmes for development aid or technical assistance have been focusing on improving access to sustainable energy, many of them with impressive results. Apart from success stories, however, experience also shows that positive appraisals of many projects evaporate after completion and vanishing of the implementation expert team. Altogether, the diffusion of sustainable technologies such as energy efficiency and renewable energy for cooking, heating, lighting, electrical appliances and building insulation in developing countries has been slow. Energy efficiency and renewable energy programmes could be more sustainable and pilot studies more effective and pulse releasing if the entire policy and implementation process was considered and redesigned from the outset [9]. New financing and implementation processes, which allow reallocating financial resources and thus enabling countries themselves to achieve a sustainable energy infrastructure, are also needed. The links between the energy policy framework, financing and implementation of renewable energy and energy efficiency projects have to be strengthened as well efforts made to increase people's knowledge through training.

\subsection{Energy use in buildings}

Buildings consume energy mainly for cooling, heating and lighting. The energy consumption was based on the assumption that the building operates within ASHRAE-thermal comfort zone during the cooling and heating periods [10]. Most of the buildings incorporate energy efficient passive cooling, solar control, photovoltaic, lighting and day lighting, and integrated energy systems. It is well known that thermal mass with night ventilation can reduce the maximum indoor temperature in buildings in summer [11]. Hence, comfort temperatures may be achieved by proper application of passive cooling systems. However, energy can also be saved if an air conditioning unit is used [12]. The reason for this is that in summer, heavy external walls delay the heat transfer from the outside into the inside spaces. Moreover, if the building has a lot of internal mass the increase in the air temperature is slow. This is 
because the penetrating heat raises the air temperature as well as the temperature of the heavy thermal mass. The result is a slow heating of the building in summer as the maximal inside temperature is reached only during the late hours when the outside air temperature is already low. The heat flowing from the inside heavy walls could be reduced with good ventilation in the evening and night. The capacity to store energy also helps in winter, since energy can be stored in walls from one sunny winter day to the next cloudy one. However, the admission of daylight into buildings alone does not guarantee that the design will be energy efficient in terms of lighting. In fact, the design for increased daylight can often raise concerns relating to visual comfort (glare) and thermal comfort (increased solar gain in the summer and heat losses in the winter from larger apertures). Such issues will clearly need to be addressed in the design of the window openings, blinds, shading devices, heating system, etc. In order for a building to benefit from daylight energy terms, it is a prerequisite that lights are switched off when sufficient daylight is available. The nature of the switching regime; manual or automated, centralised or local, switched, stepped or dimmed, will determine the energy performance. Simple techniques can be implemented to increase the probability that lights are switched off [13]. These include:

- Making switches conspicuous and switching banks of lights independently.

- Loading switches appropriately in relation to the lights.

- Switching banks of lights parallel to the main window wall.

There are also a number of methods, which help reduce the lighting energy use, which, in turn, relate to the type of occupancy pattern of the building [13]. The light switching options include:

- Centralised timed off (or stepped)/manual on.

- Photoelectric off (or stepped)/manual on.

- Photoelectric and on (or stepped), photoelectric dimming.

- Occupant sensor (stepped) on/off (movement or noise sensor).

Likewise, energy savings from the avoidance of air conditioning can be very substantial. Whilst day-lighting strategies need to be integrated with artificial lighting systems in order to become beneficial in terms of energy use, reductions in overall energy consumption levels by employment of a sustained programme of energy consumption strategies and measures would have considerable benefits within the buildings sector. It would perhaps be better to support a climate sensitive design approach that encompasses some elements of the pure conservation strategy together with strategies, which work with the local ambient conditions making use of energy technology systems, such as solar energy, where feasible. In practice, low energy environments are achieved through a combination of measures that include:

- The application of environmental regulations and policy.

- The application of environmental science and best practice.

- Mathematical modelling and simulation.

- Environmental design and engineering.

- Construction and commissioning.

- Management and modifications of environments in use.

While the overriding intention of passive solar energy design of buildings is to achieve a reduction in purchased energy consumption, the attainment of significant savings is in doubt. The non-realisation of potential energy benefits is mainly due to the neglect of the consideration of post-occupancy user and management behaviour by energy scientists and designers alike. Calculating energy inputs in agricultural production is more difficult in comparison to the industry sector due to the high number of factors affecting agricultural production, as Table 1 shows. However, considerable studies have been conducted in different countries on energy use in agriculture [14-19] in order to quantify the influence of these factors. 


\section{Renewable energy technologies}

Sustainable energy is the energy that, in its production or consumption, has minimal negative impacts on human health and the healthy functioning of vital ecological systems, including the global environment. It is an accepted fact that renewable energy is a sustainable form of energy, which has attracted more attention during recent years. Increasing environmental interest, as well as economic consideration of fossil fuel consumption and high emphasis of sustainable development for the future helped to bring the great potential of renewable energy into focus. Nearly a fifth of all global power is generated by renewable energy sources, according to a book published by the OECD/IEA [20]. "Renewables for power generation: status and prospects" claims that, at approximately $20 \%$, renewables are the second largest power source after coal (39\%) and ahead of nuclear (17\%), natural gas (17\%) and oil (8\%) respectively. From 1973-2000 renewables grew at $9.3 \%$ a year and it is predicted that this will increase by $10.4 \%$ a year to 2010 . Wind power grew fastest at $52 \%$ and will multiply seven times by 2010 , overtaking biopower and hence help reducing green house gases, GHGs, emissions to the environment.

Table 2 shows some applications of different renewable energy sources. The challenge is to match leadership in GHG reduction and production of renewable energy with developing a major research and manufacturing capacity in environmental technologies (wind, solar, fuel cells, etc.). More than $50 \%$ of the world's area is classified as arid, representing the rural and desert part, which lack electricity and water networks. The inhabitants of such areas obtain water from borehole wells by means of water pumps, which are mostly driven by diesel engines. The diesel motors are associated with maintenance problems, high running cost, and environmental pollution. Alternative methods are pumping by photovoltaic (PV) or wind systems. At present, renewable sources of energy are regional and site specific. It has to be integrated in the regional development plans. Rasslavicius, Grzybek, and Dubrovin (2011) investigated prospects of bioenergy in Lithuania and Ukraine and put emphasis on agricultural waste-for-energy production technologies as well as on impact of bioenergy towards the improvement of the quality of life in rural communities [36]. Guilherme, Luiz, and Legey (2013) investigated energy from sugarcane bagasse in Brazil: An assessment of the productivity and cost of different technological routes [37].

\subsection{Solar energy}

The availability of data on solar radiation is a critical problem. Even in developed countries, very few weather stations have been recording detailed solar radiation data for a period of time long enough to have statistical significance. Solar radiation arriving on earth is the most fundamental renewable energy source in nature. It powers the bio-system, the ocean and atmospheric current system and affects the global climate. Reliable radiation information is needed to provide input data in modelling solar energy devices and a good database is required in the work of energy planners, engineers, and agricultural scientists. In general, it is not easy to design solar energy conversion systems when they have to be installed in remote locations. First, in most cases, solar radiation measurements are not available for these sites. Second, the radiation nature of solar radiation makes the computation of the size of such systems difficult. While solar energy data are recognised as very important, their acquisition is by no means straightforward. The measurement of solar radiation requires the use of costly equipment such as pyrheliometers and pyranometers. Consequently, adequate facilities are often not available in developing countries to mount viable monitoring programmes. This is partly due to the equipment cost as well as the cost of technical manpower. Several attempts have, however, been made to estimate solar radiation through the use of meteorological and other physical parameter in order to avoid the use of expensive network of measuring instruments [21-24].

Two of the most essential natural resources for all life on the earth and for man's survival are sunlight and water. Sunlight is the driving force behind many of the RETs. The worldwide potential for utilising this resource, both directly by means of the solar technologies and indirectly by means of biofuels, wind and hydro technologies, is vast. During the last decade interest has been refocused on renewable energy sources due to the increasing prices and fore-seeable exhaustion of presently used commercial 
energy sources. The most promising solar energy technology are related to thermal systems; industrial solar water heaters, solar cookers, solar dryers for peanut crops, solar stills, solar driven cold stores to store fruits and vegetables, solar collectors, solar water desalination, solar ovens, and solar commercial bakers.

Table 1 Energy equivalent of inputs and outputs [25]

\begin{tabular}{|l|c|c|}
\hline Energy source & Unit & Equivalent energy (MJ) \\
\hline Input & & \\
1. Human labour & $\mathrm{h}$ & 2.3 \\
2. Animal labour & $\mathrm{h}$ & 10.10 \\
Horse & $\mathrm{h}$ & 4.04 \\
Mule & $\mathrm{h}$ & 4.04 \\
Donkey & $\mathrm{h}$ & 5.05 \\
Cattle & $\mathrm{h}$ & 7.58 \\
Water buffalo & $\mathrm{kWh}$ & 11.93 \\
3. Electricity & $\mathrm{Litre}$ & 56.31 \\
4. Diesel & & \\
5. Chemicals fertilisers & $\mathrm{kg}$ & 64.4 \\
Nitrogen & $\mathrm{kg}$ & 11.96 \\
$\mathrm{P}_{2} \mathrm{O}_{5}$ & $\mathrm{~kg}$ & 6.7 \\
$\mathrm{~K}_{2} \mathrm{O}$ & & \\
6. Seed & $\mathrm{kg}$ & 25 \\
Cereals and pulses & $\mathrm{kg}$ & 3.6 \\
Oil seed & $\mathrm{kg}$ & 14.7 \\
Tuber & $\mathrm{kg}$ & 43.3 \\
Total input & & \\
Output & $\mathrm{kg}$ & \\
7. Major products & $\mathrm{kg}$ & 14.7 \\
Cereal and pulses & $\mathrm{kg}$ & 5.04 \\
Sugar beet & $\mathrm{kg}$ & 0.8 \\
Tobacco & $\mathrm{kg}$ & 11.8 \\
Cotton & $\mathrm{kg}$ & 25 \\
Oil seed & $\mathrm{kg}$ & 1.9 \\
Fruits & $\mathrm{kg}$ & 0.8 \\
Vegetables & $\mathrm{kg}$ & 1.9 \\
Water melon & $\mathrm{kg}$ & 1.6 \\
Onion & $\mathrm{kg}$ & 3.6 \\
Potatoes & $\mathrm{kg}$ & 11.8 \\
Olive & $\mathrm{kg}$ & 0.8 \\
Tea & $\mathrm{kg}$ & 13.8 \\
8. By products & & 12.5 \\
Husk & $\mathbf{1 4 9 . 0 4}$ \\
Straw & Cob & \\
Cob & Seed cotton & \\
Total output & & \\
& & \\
\hline
\end{tabular}

Solar PV system: solar PV for lighting, solar refrigeration to store vaccines for human and animal use, solar PV for water pumping, solar PV for battery chargers, solar PV for communication 
network, microwave, receiver stations, radio systems in airports, VHF and beacon radio systems in airports, and educational solar TV posts in villages. Solar pumps are most cost effective for low power requirement (up to $5 \mathrm{~kW}$ ) in remote places. Applications include domestic and livestock drinking water supplies, for which the demand is constant throughout the year, and irrigation. However, the suitability of solar pumping for irrigation, though possible, is uncertain because the demand may vary greatly with seasons. Solar systems may be able to provide trickle irrigation for fruit farming, but not usually the large volumes of water needed for wheat growing.

The hydraulic energy required to deliver a volume of water is given by the formula:

$\mathrm{E}_{\mathrm{w}}=\rho_{\mathrm{w}} \mathrm{gVH}$

Where $E_{\mathrm{w}}$ is the required hydraulic energy $\left(\mathrm{kWhday}^{-1}\right) ; \rho_{\mathrm{w}}$ is the water density $\left(\mathrm{kgm}^{-3}\right)$; $\mathrm{g}$ is the gravitational acceleration $\left(\mathrm{ms}^{-2}\right) ; \mathrm{V}$ is the required volume of water $\left(\mathrm{m}^{3} \mathrm{day}^{-1}\right)$; and $\mathrm{H}$ is the head of water $(\mathrm{m})$.

Table 2 Sources of renewable energy

\begin{tabular}{|c|c|c|}
\hline Energy source & Technology & Size \\
\hline Solar energy & $\begin{array}{l}\text { - } \quad \text { Domestic solar water heaters } \\
\text { - Solar water heating for large demands } \\
\text { - PV roofs: grid connected systems generating } \\
\text { electric energy }\end{array}$ & $\begin{array}{l}\text { Small } \\
\text { Medium-large } \\
\text { Medium-large }\end{array}$ \\
\hline Wind energy & - Wind turbines (grid connected) & Medium-large \\
\hline Hydraulic energy & $\begin{array}{l}\text { - Hydro plants in derivation schemes } \\
\text { - Hydro plants in existing water distribution } \\
\text { networks }\end{array}$ & $\begin{array}{l}\text { Medium-small } \\
\text { Medium-small }\end{array}$ \\
\hline Biomass & $\begin{array}{ll}\text { - } & \text { High efficiency wood boilers } \\
\text { - } & \text { CHP plants fed by agricultural wastes or } \\
& \text { energy crops } \\
\text { - } & \text { Fuel alcohol by biological fermentation } \\
\text { - } & \text { Fermentation using corn } \\
\text { - } & \text { Fermentation using sugarcane } \\
\text { - } & \text { Cellulose of wood and grass } \\
\text { - } & \text { Biodiesel }\end{array}$ & $\begin{array}{l}\text { Small } \\
\text { Medium } \\
\text { medium } \\
\text { Wide } \\
\text { Wide } \\
\text { Wide } \\
\text { Wide }\end{array}$ \\
\hline Animal manure & - $\quad$ CHP plants fed by biogas & Small \\
\hline $\mathrm{CHP}$ & $\begin{array}{l}\text { - } \text { High efficiency lighting } \\
\text { - High efficiency electric } \\
\text { - Householders appliances } \\
\text { - High efficiency boilers } \\
\text { - } \quad \text { Plants coupled with refrigerating absorption } \\
\text { machines }\end{array}$ & $\begin{array}{l}\text { Wide } \\
\text { Wide } \\
\text { Wide } \\
\text { Small-medium } \\
\text { Medium-large }\end{array}$ \\
\hline
\end{tabular}

The solar array power required is given by:

$\mathrm{P}_{\mathrm{sa}}=\mathrm{E}_{\mathrm{w}} / \mathrm{E}_{\mathrm{sr}} \eta \mathrm{F}$

Where: $\mathrm{P}_{\mathrm{sa}}$ is the solar array power $\left(\mathrm{kW}_{\mathrm{p}}\right) ; \mathrm{E}_{\mathrm{sr}}$ is the average daily solar radiation $\left(\mathrm{kWhm}^{-2}\right.$ day $\left.^{-1}\right)$; $\mathrm{F}$ is the array mismatch factor; and $\eta$ is the daily subsystem efficiency.

Substituting Eq. (1) in Eq. (2), the following equation is obtained for the amount of water that can be pumped: 
$\mathrm{V}=\mathrm{P}_{\mathrm{sa}} \mathrm{E}_{\mathrm{sr}} \eta \mathrm{F} / \rho_{\mathrm{w}} \mathrm{g} \mathrm{H}$

$\mathrm{P}_{\mathrm{sa}}=1.6 \mathrm{~kW}_{\mathrm{p}}, \mathrm{F}=0.85, \eta=40 \%$.

A further increase of PV depends on the ability to improve the durability, performance and the local manufacturing capabilities of PV.

\subsection{Biomass}

The data required to perform the trade-off analysis simulation of bio-energy resources can be classified according to the divisions given in Table 3, namely the overall system or individual plants, and the existing situation or future development. The effective economical utilisations of these resources are shown in Table 4, but their use is hindered by many problems such as those related to harvesting, collection, and transportation, besides the photo-sanitary control regulations. Biomass energy is experiencing a surge in interest stemming from a combination of factors, e.g., greater recognition of its current role and future potential contribution as a modern fuel, global environmental benefits, its development and entrepreneurial opportunities, etc. Possible routes of biomass energy development are shown in Table 5. However, biomass usage and application can generally be divided into the following three categories:

\begin{tabular}{|c|c|c|}
\hline $\begin{array}{l}\text { Biomass energy for petroleum } \\
\text { substitution driven by the } \\
\text { following factor }\end{array}$ & $\begin{array}{l}\text { Biomass energy for domestic } \\
\text { needs driven by }\end{array}$ & $\begin{array}{l}\text { Biomass energy } \\
\text { development driven by }\end{array}$ \\
\hline $\begin{array}{l}\text { Oil price increase } \\
\text { Balance of payment problems, } \\
\text { and economic crisis } \\
\text { Fuel-wood plantations and } \\
\text { residue utilisation } \\
\text { Wood based heat and electricity } \\
\text { Liquid fuels from biomass } \\
\text { Producer gas technology }\end{array}$ & $\begin{array}{l}\text { Population increase } \\
\text { Urbanisation } \\
\text { Agricultural expansion } \\
\text { Fuel-wood crisis } \\
\text { Ecological crisis } \\
\text { Fuel-wood plantations, agro- } \\
\text { forestry } \\
\text { Community forestry, and } \\
\text { residue utilisation } \\
\text { Improved stoves, and improved } \\
\text { charcoal production }\end{array}$ & $\begin{array}{l}\text { Electrification } \\
\text { Irrigation and water supply } \\
\text { Economic and social } \\
\text { development } \\
\text { Fuel-wood plantations } \\
\text { Community forestry } \\
\text { Agro-forestry } \\
\text { Briquettes } \\
\text { Producer gas technology }\end{array}$ \\
\hline
\end{tabular}

Table 3 Classifications of data requirements

\begin{tabular}{|l|l|l|}
\hline Criteria & Plant data & System data \\
\hline Existing data & Size & Peak load \\
& Life & Load shape \\
& Cost (fixed and variation operation and & Capital costs \\
& maintenance) & Fuel costs \\
& Forced outage & Depreciation \\
& Maintenance & Rate of return \\
& Efficiency & Taxes \\
& Fuel & \\
& Emissions & System lead growth \\
\hline Future data & All of above, plus & Fuel price growth \\
& Capital costs & Fuel import limits \\
& Construction trajectory & Inflation \\
\hline
\end{tabular}

The use of biomass through direct combustion has long been, and still is, the most common mode of biomass utilisation (Table 5). Examples for dry (thermo-chemical) conversion processes are 
charcoal making from wood (slow pyrolysis), gasification of forest and agricultural residues (fast pyrolysis - this is still in demonstration phase), and of course, direct combustion in stoves, furnaces, etc. Wet processes require substantial amount of water to be mixed with the biomass. Biomass technologies include:

- Carbonisation and briquetting.

- Improved stoves.

- Biogas.

- Improved charcoal.

- Gasification.

Table 4 Effective biomass resource utilisation

\begin{tabular}{|c|c|c|}
\hline Subject & Tools & Constraints \\
\hline $\begin{array}{l}\text { Utilisation and land } \\
\text { clearance for agriculture } \\
\text { expansion }\end{array}$ & $\begin{array}{ll}\text { - } & \text { Stumpage fees } \\
\text { - } & \text { Control } \\
\text { - } & \text { Extension } \\
\text { - } & \text { Conversion } \\
\text { - } & \text { Technology }\end{array}$ & $\begin{array}{ll}\text { - } & \text { Policy } \\
\text { - } & \text { Fuel-wood planning } \\
\text { - } & \text { Lack of extension } \\
\text { - } & \text { Institutional }\end{array}$ \\
\hline $\begin{array}{l}\text { Utilisation of agricultural } \\
\text { residues }\end{array}$ & $\begin{array}{ll}\text { - } & \text { Briquetting } \\
\text { - } & \text { Carbonisation } \\
\text { - } & \text { Carbonisation and } \\
& \text { briquetting } \\
\text { - } & \text { Fermentation } \\
\text { - } & \text { Gasification }\end{array}$ & $\begin{array}{ll} & \text { Capital } \\
\text { - } & \text { Pricing } \\
\text { - } & \text { Policy and legislation } \\
\text { - } & \text { Social acceptability }\end{array}$ \\
\hline
\end{tabular}

\subsubsection{Briquetting and Carbonisation}

Briquetting is the formation of a char (an energy-dense solid fuel source) from otherwise wasted agricultural and forestry residues. One of the disadvantages of wood fuel is that it is bulky with a low energy density and therefore requires transport. Briquette formation allows for a more energydense fuel to be delivered, thus reducing the transportation cost and making the resource more competitive. It also adds some uniformity, which makes the fuel more compatible with systems that are sensitive to the specific fuel input. Charcoal stoves are very familiar to African societies. As for the stove technology, the present charcoal stove can be used, and can be improved upon for better efficiency. This energy term will be of particular interest to both urban and rural households and all the income groups due to its simplicity, convenience, and lower air polluting characteristics. However, the market price of the fuel together with that of its end-use technology may not enhance its early high market penetration especially in the urban low income and rural households.

Charcoal is produced by slow heating wood (carbonisation) in airtight ovens or retorts, in chambers with various gases, or in kilns supplied with limited and controlled amounts of air. The charcoal yield decreased gradually from 42.6 to $30.7 \%$ for the hazelnut shell and from 35.6 to $22.7 \%$ for the beech wood with an increase of temperature from 550 to $1,150{ }^{\circ} \mathrm{K}$ while the charcoal yield from the lignin content decreases sharply from 42.5 to $21.7 \%$ until it was at $850{ }^{\circ} \mathrm{K}$ during the carbonisation procedures [25]. The charcoal yield decreases as the temperature increases, while the ignition temperature of charcoal increases as the carbonisation temperature increases. The charcoal briquettes that are sold on the commercial market are typically made from a binder and filler.

\subsubsection{Improved cook stoves}

Traditional wood stoves are commonly used in many rural areas. These can be classified into four types: three stone, metal cylindrical shaped, metal tripod and clay type. Indeed, improvements of 
traditional cookers and ovens to raise the efficiency of fuel saving can secure rural energy availability, where woody fuels have become scarce. However, planting fast growing trees to provide a constant fuel supply should also be considered. The rural development is essential and economically important since it will eventually lead to a better standard of living, people's settlement, and self-sufficiency.

\subsubsection{Biogas}

Biogas technology cannot only provide fuel, but is also important for comprehensive utilisation of biomass forestry, animal husbandry, fishery, agricultural economy, protecting the environment, realising agricultural recycling as well as improving the sanitary conditions, in rural areas. However, the introduction of biogas technology on a wide scale has implications for macro planning such as the allocation of government investment and effects on the balance of payments. Hence, factors that determine the rate of acceptance of biogas plants, such as credit facilities and technical backup services, are likely to have to be planned as part of general macro-policy, as do the allocation of research and development funds [25].

Table 5 Agricultural residues routes for development

\begin{tabular}{|c|c|c|c|}
\hline Source & Process & Product & End use \\
\hline Agricultural residues & $\begin{array}{l}\text { Direct } \\
\text { Processing } \\
\text { Processing } \\
\text { Carbonisation } \\
\text { Fermentation }\end{array}$ & $\begin{array}{l}\text { Combustion } \\
\text { Briquettes } \\
\text { Carbonisation } \\
\text { (small scale) } \\
\text { Briquettes } \\
\text { Carbonised } \\
\text { Biogas }\end{array}$ & $\begin{array}{l}\text { Rural poor } \\
\text { Urban household } \\
\text { Industrial use } \\
\text { Industrial use } \\
\text { Limited household use } \\
\text { Rural household (self } \\
\text { sufficiency) } \\
\text { Urban fuel } \\
\text { Energy services } \\
\text { Household, and industry }\end{array}$ \\
\hline $\begin{array}{l}\text { Agricultural, and } \\
\text { animal residues }\end{array}$ & $\begin{array}{l}\text { Direct } \\
\text { Briquettes } \\
\text { Carbonisation } \\
\text { Carbonisation } \\
\text { Fermentation }\end{array}$ & $\begin{array}{l}\text { Combustion } \\
\text { Direct } \\
\text { combustion } \\
\text { Carbonised } \\
\text { Briquettes } \\
\text { Biogas }\end{array}$ & $\begin{array}{l}\text { (Save or less efficiency as } \\
\text { wood) } \\
\text { (Similar end use devices or } \\
\text { improved) } \\
\text { Use } \\
\text { Briquettes use } \\
\text { Use }\end{array}$ \\
\hline
\end{tabular}

\subsubsection{Improved charcoal}

Dry cell batteries are a practical but expensive form of mobile fuel that is used by rural people when moving around at night and for powering radios and other small appliances. The high cost of dry cell batteries is financially constraining for rural households, but their popularity gives a good indication of how valuable a versatile fuel like electricity is in rural areas (Table 2.6). However, dry cell batteries can constitute an environmental hazard unless they are recycled in a proper fashion. Tables (6-7) further show that direct burning of fuel-wood and crop residues constitute the main usage of biomass, as is the case with many developing countries. In fact, biomass resources play a significant role in energy supply in all developing countries. However, the direct burning of biomass in an inefficient manner causes economic loss and adversely affects human health. In order to address the problem of inefficiency, research centres around the world, e.g., [25] have investigated the viability of converting the resource to a more useful form of improved charcoal, namely solid briquettes and fuel gas. Accordingly, biomass resources should be divided into residues or dedicated resources, the latter including firewood and charcoal can also be produced from forest residues (Table 7). Whichever form 
of biomass resource used, its sustainability would primarily depend on improved forest and tree management.

\subsubsection{Gasification}

Gasification is based on the formation of a fuel gas (mostly $\mathrm{CO}$ and $\mathrm{H}_{2}$ ) by partially oxidising raw solid fuel at high temperatures in the presence of steam or air. The technology can use wood chips, groundnut shells, sugar cane bagasse, and other similar fuels to generate capacities from $3 \mathrm{~kW}$ to 100 $\mathrm{kW}$. Many types of gasifier designs have been developed to make use of the diversity of fuel inputs and to meet the requirements of the product gas output (degree of cleanliness, composition, heating value, etc.) [25].

Table 6 Energy carrier and energy services in rural areas

\begin{tabular}{|l|l|}
\hline Energy carrier & Energy end-use \\
\hline Fuel-wood & $\begin{array}{l}\text { Cooking } \\
\text { Water heating } \\
\text { Building materials } \\
\text { Animal fodder preparation }\end{array}$ \\
\hline Kerosene & $\begin{array}{l}\text { Lighting } \\
\text { Ignition fires }\end{array}$ \\
\hline Dry cell batteries & $\begin{array}{l}\text { Lighting } \\
\text { Small appliances }\end{array}$ \\
\hline Animal power & $\begin{array}{l}\text { Transport } \\
\text { Land preparation for farming } \\
\text { Food preparation (threshing) }\end{array}$ \\
\hline Human power & $\begin{array}{l}\text { Transport } \\
\text { Land preparation for farming } \\
\text { Food preparation (threshing) }\end{array}$ \\
\hline
\end{tabular}

Table 7 Biomass residues and current use

\begin{tabular}{|l|l|}
\hline Type of residue & Current use \\
\hline Wood industry waste & Residues available \\
\hline Vegetable crop residues & Animal feed \\
\hline Food processing residue & Energy needs \\
\hline Sorghum, millet, wheat residues & Fodder, and building materials \\
\hline Groundnut shells & Fodder, brick making, direct fining oil mills \\
\hline Cotton stalks & $\begin{array}{l}\text { Domestic fuel considerable amounts available for short } \\
\text { period }\end{array}$ \\
\hline Sugar, bagasse, molasses & Fodder, energy need, ethanol production (surplus available) \\
\hline Manure & Fertiliser, brick making, plastering \\
\hline
\end{tabular}

Application of biomass- fuel alcohol produced by biological fermentation is hugely important. There are a lot of fuel alcohol plants in USA (fermentation using corn), and Brazil (fermentation using sugarcane) [37]. Other countries use cellulose of wood and grass. Biodiesel is also a potential renewable fuel which can be extracted initially from several sorts of plant seeds in the flora of southern China. The Netherlands purchased millions of tons of used cooking oil from China for combustion of airplane engines [38].

\subsubsection{Biomass and sustainability}

A sustainable energy system includes energy efficiency, energy reliability, energy flexibility, fuel poverty, and environmental impacts. A sustainable biofuel has two favourable properties, which 
are availability from renewable raw material, and its lower negative environmental impact than that of fossil fuels. Global warming, caused by $\mathrm{CO}_{2}$ and other substances, has become an international concern in recent years. To protect forestry resources, which act as major absorbers of $\mathrm{CO}_{2}$, by controlling the ever-increasing deforestation and the increase in the consumption of wood fuels, such as firewood and charcoal, is therefore an urgent issue. Given this, the development of a substitute fuel for charcoal is necessary. Briquette production technology, a type of clean coal technology, can help prevent flooding and serve as a global warming countermeasure by conserving forestry resources through the provision of a stable supply of briquettes as a substitute for charcoal and firewood.

There are many emerging biomass technologies with large and immediate potential applications, e.g., biomass gasifier/gas turbine (BGST) systems for power generation with pilot plants, improved techniques for biomass harvesting, transportation and storage. Gasification of crop residues such as rice husks, groundnut shells etc. with plants already operating in China, India, and Thailand. Treatment of cellulosic materials by steam explosion which may be followed by biological or chemical hydrolysis to produce ethanol or other fuels, cogeneration technologies, hydrogen from biomass, striling energies capable of using biomass fuels efficiently, etc. Table 8 gives a view of the use of Biomass and its projection worldwide.

However, a major gap with biomass energy is that research has usually been aimed at obtaining supply and consumption data, with insufficient attention and resources being allocated to basic research, to production, harvesting and conservation processes. Biomass has not been closely examined in terms of a substitute for fossil fuels compared to carbon sequestration and overall environmental benefits related to these different approaches. To achieve the full potential of biomass as a feedstock for energy, food, or any other use, requires the application of considerable scientific and technological inputs [25-26]. However, the aim of any modern biomass energy systems must be:

(1) To maximise yields with minimum inputs.

(2) Utilise and select adequate plant materials and processes.

(3) Optimise use of land, water, and fertiliser.

(4) Create an adequate infrastructure and strong R\&D base.

Table 8 Final energy projections including biomass (Mtoe) [27]

\begin{tabular}{|c|c|c|c|c|}
\hline \multirow[t]{2}{*}{ Region } & \multicolumn{2}{|c|}{2011} & \multirow[b]{2}{*}{ Total } & \multirow[b]{2}{*}{$\begin{array}{c}\text { Share of } \\
\text { Biomass }(\%\end{array}$} \\
\hline & Biomass & $\begin{array}{c}\text { Conventional } \\
\text { Energy }\end{array}$ & & \\
\hline Africa & 205 & 136 & 341 & 60 \\
\hline China & 206 & 649 & 855 & 24 \\
\hline East Asia & 106 & 316 & 422 & 25 \\
\hline Latin America & 73 & 342 & 416 & 18 \\
\hline South Asia & 235 & 188 & 423 & 56 \\
\hline Total developing countries & 825 & 1632 & 2456 & 34 \\
\hline Other non-OECD countries & 24 & 1037 & 1061 & 1 \\
\hline Total non-OECD countries & 849 & 2669 & 3518 & 24 \\
\hline OECD countries & 81 & 3044 & 3125 & 3 \\
\hline World & 930 & 5713 & 6643 & 14 \\
\hline \multicolumn{2}{|l|}{ Region } & \multicolumn{3}{|c|}{2020} \\
\hline & Biomass & $\begin{array}{c}\text { Conventional } \\
\text { Energy }\end{array}$ & Total & $\begin{array}{c}\text { Share of } \\
\text { Biomass }(\%)\end{array}$ \\
\hline Africa & 371 & 266 & 631 & 59 \\
\hline China & 224 & 1524 & 1748 & 13 \\
\hline East Asia & 118 & 813 & 931 & 13 \\
\hline Latin America & 81 & 706 & 787 & 10 \\
\hline South Asia & 276 & 523 & 799 & 35 \\
\hline Total developing countries & 1071 & 3825 & 4896 & 22 \\
\hline
\end{tabular}




\begin{tabular}{|l|c|c|c|c|}
\hline Other non-OECD countries & 26 & 1669 & 1695 & 1 \\
\hline Total non-OECD countries & 1097 & 5494 & 6591 & 17 \\
\hline OECD countries & 96 & 3872 & 3968 & 2 \\
\hline World & $\mathbf{1 1 9 3}$ & $\mathbf{9 3 6 5}$ & $\mathbf{1 0 5 5 8}$ & $\mathbf{1 1}$ \\
\hline
\end{tabular}

An afforestation programme appears an attractive option for any country to pursue in order to reduce the level of atmospheric carbon by enhancing carbon sequestration in the nation's forests, which would consequently mitigate climate change. However, it is acknowledged that certain barriers need to be overcome if the objectives are to be fully achieved [28-34]. These include the followings.

- Low level of public awareness of the economic/environmental benefits of forestry.

- The generally low levels of individuals' income.

- Pressures from population growth.

- The land tenural system, which makes it difficult (if at all possible) for individuals to own or establish forest plantations.

- Poor pricing of forest products especially in the local market.

- Inadequate financial support on the part of governments.

- Weak institutional capabilities of the various Forestry Departments as regards technical manpower to effectively manage tree plantations.

However, social policy conditions are also critical. This is still very much lacking particularly under developing countries conditions. During the 1970s and 1980s different biomass energy technologies were perceived in sub-Saharan Africa as a panacea for solving acute problems. On the account of these expectations, a wide range of activities and projects were initiated. However, despite considerable financial and human efforts, most of these initiatives have unfortunately been a failure.

Therefore, future research efforts should concentrate on the following areas.

- Directed $\mathrm{R}$ and $\mathrm{D}$ in the most promising areas of biomass to increase energy supply and to improve the technological base.

- Formulate a policy framework to encourage entrepreneurial and integrated process.

- Pay more attention to sustainable production and use of biomass energy feedstocks, methodology of conservation and efficient energy flows.

- More research aimed at pollution abatement.

- Greater attentions to interrelated socio-economic aspects.

- Support R and D on energy efficiency in production and use.

- Improve energy management skills and take maximum advantage of existing local knowledge.

- Closely examine past successes and failures to assist policy makers with well-informed recommendations.

\section{Nuclear Energy}

Eventually renewable energies will dominate the world's energy supply system. There is no real alternative. Humankind cannot indefinitely continue to base its life on the consumption of finite energy resources. Today, the world's energy supply is largely based on fossil fuels and nuclear power. These sources of energy will not last forever and have proven to be contributors to our environmental problems.Renewables for power generation: status and prospects claims that renewables are the second largest power source after coal (39\%) and ahead of nuclear (17\%), natural gas (17\%) and oil (8\%). From 1973-2000 renewables grew at 9.3\% a year, and the authors predict this will increase $10.4 \%$ a year to 2020 [35-38].

The nuclear power market potential suggests that nuclear power has the potential to help reduce dependence on fossil fuels and curb $\mathrm{CO}_{2}$ emissions in a cost-effective way, since its uranium fuel is abundant. However, governments must take a more active role in facilitating private investment, 
especially in liberalised electricity markets where the trade-off between security and low price has been a disincentive to investment in new plant and grid infrastructure. Investment of $\$ 20.2$ trillion will be required by 2030 under the International Energy Association (IEA) alternative energy scenario, increasing nuclear capacity by $41 \%$ to $519 \mathrm{GWe}$ and reducing energy demand by $10 \%$ and $\mathrm{CO}_{2}$ emissions by $16 \%$ compared with projections on present basis. Of this amount, $\$ 11.3$ trillion will go for electricity, \$5.2 trillion for generation, and the rest for transmission and distribution.

The major issues affecting the nuclear power industry, including:

- Technologies for new nuclear facilities.

- Nuclear fuel cycle and nuclear waste disposal.

- Nuclear Regulation.

- Non proliferation goals.

- Energy security.

- Global nuclear energy partnership.

- Nuclear weapons.

Today, the world produces as much electricity from nuclear energy as it did from all sources combined in 1960. Civil nuclear power can now boast more than 12,400 reactor years of experience. Nuclear energy supplies $16 \%$ of global needs in 30 countries. Nuclear technology uses energy released by splitting the atoms of certain elements. Its applications range from bomb production to power generation. It was first developed in the 1940s, and during World War II research focused on producing bombs by splitting atoms of uranium or plutonium. In the 1950s, attention turned to peaceful applications for nuclear fission, notably power generation. Nuclear power generation is an established part of the world's electricity mix providing over $16 \%$ of the world's electricity (cf. coal $40 \%$, oil $10 \%$, natural gas $15 \%$, and hydro and other 19\%). It is particularly suitable for large-scale, base-load electricity demand. Although fewer nuclear power plants are being built now than during the 1970s and 1980s, those that are operating produce more electricity. In 2005, production was 2626 billion kWh. The increase over the last five years (218 TWh) is equal to the output from 30 large new nuclear plants. Yet between 1999 and 2005, there was a net increase of only 2 reactors and $15 \mathrm{GWe}$ ). The rest of the increase is due to better performance from existing units. With the United Nations predicting the world's population to increase from 6.4 billion in 2010 to 8.1 billion by 2030 , demand for energy will inevitably increase substantially. Both population growth and increasing standards of living for many people in developing countries will create strong growth in energy demand, expected to be $1.6 \%$ year or $53 \%$ from 2010 to 2030.

Nuclear power is a type of nuclear technology involving the controlled use of nuclear reactions, usually nuclear fission, to release energy for work including propulsion, heat, and the generation of electricity. Nuclear energy is produced by a controlled nuclear chain reaction and creates heat - which is used to boil water, produce steam, and drive a steam turbine. A nuclear reactor is a device in which nuclear chain reactions are initiated, controlled, and sustained at a steady rate, as opposed to a nuclear bomb, in which the chain reaction occurs in a fraction of a second and is uncontrolled causing an explosion. The most significant use of nuclear reactors is as an energy source for the generation of electrical power and for the power in some ships. This is usually accomplished by methods that involve using heat from the nuclear reaction to power steam turbines. The United States produces the most nuclear energy, with nuclear power providing $20 \%$ of the electricity it consumes, while France produces the highest percentage of its electrical energy from nuclear reactors $80 \%$ as of 2006 . In the European Union as a whole, nuclear energy provides $30 \%$ of the electricity. Nuclear energy policy differs between the European Union countries, and some, such as Austria and Ireland, have no active nuclear power stations. In comparison, France has a large number of these plants, with 16 multi-unit stations in current use. Analysis of the major nuclear power plants in the United States takes a view of the overall nuclear power industry worldwide, with an analysis of the basics of nuclear power and an 
overview of the nuclear power industry in the United States (75 plants). Conventional and centralised electricity networks are the norm in the developed world. However, the present energy infrastructure of the developed countries was mainly created during the monopolistic utility era of the past.

\section{Conclusions}

There is strong scientific evidence that the average temperature of the earth's surface is rising. This is a result of the increased concentration of carbon dioxide and other GHGs in the atmosphere as released by burning fossil fuels. This global warming will eventually lead to substantial changes in the world's climate, which will, in turn, have a major impact on human life and the built environment. Therefore, effort has to be made to reduce fossil energy use and to promote green energy, particularly in the building sector. Energy use reductions can be achieved by minimising the energy demand, rational energy use, recovering heat and the use of more green energy. This study was a step towards achieving this goal.

\section{References}

[1] Cantrell, J., and Wepfer, W. (1984). Shallow Ponds for Dissipation of Building Heat: A case Study. ASHRAE Transactions 90 (1): 239-246.

[2] ASHRAE. (1995). Commercial/Institutional Ground Source Heat Pump Engineering Manual. American Society of heating, Refrigeration and Air-conditioning Engineers, Inc. Atlanta, GA: USA.

[3] Kavanaugh, S., Rafferty, K. (1997). Ground source heat pumps. Design of Geothermal Systems for Commercial and Institutional Buildings. American Society of heating, Refrigeration and Air-conditioning Engineers, Inc. Atlanta, GA: USA.

[4] United Nations. (2003). World urbanisation project: the 2002 revision. New York: The United Nations Population Division.

[5] The United Nations Framework Convention on Climate Change (UNFCCC). (2009). The draft of the Copenhagen Climate Change Treaty. p. 3-181.

[6] Rees, W.E. (1999). The built environment and the ecosphere: a global perspective. Building Research and information 1999; 27(4): 206-20.

[7] Bos, E., My, T., Vu, E. and Bulatao, R. (1994). World population projection: 1994-95. Baltimore and London: World Bank by the John Hopkins University Press; 1994.

[8] Duchin, F. (1995). Global scenarios about lifestyle and technology, the sustainable future of the global system. Tokyo: United Nations University; 1995.

[9] Givoni, B. (1998). Climate consideration in building and urban design. New York: Van Nostrand Reinhold; 1998.

[10] ASHRAE. (1993). Energy efficient design of new building except new low-rise residential buildings. BSRIASHRAE proposed standards 90-2P-1993, alternative GA. American Society of Heating, Refrigerating, and Air Conditioning Engineers Inc., USA. 1993.

[11] Kammerud, R., Ceballos, E., Curtis, B., Place, W., and Anderson, B. (1984). Ventilation cooling of residential buildings. ASHRAE Trans: 90 Part 1B, 1984.

[12] Shaviv, E. (1989). The influence of the thermal mass on the thermal performance of buildings in summer and winter. In: Steemers TC, Palz W., editors. Science and Technology at the service of architecture. Dordrecht: Kluwer Academic Publishers, 1989. p. 470-2.

[13] Singh, J. (2000). On farm energy use pattern in different cropping systems in Haryana, India. Germany: International Institute of Management-University of Flensburg, Sustainable Energy Systems and Management, Master of Science; 2000.

[14] CAEEDAC. (2000). A descriptive analysis of energy consumption in agriculture and food sector in Canada. Final Report, February 2000.

[15] Yaldiz, O., Ozturk, H., Zeren, Y. (1993). Energy usage in production of field crops in Turkey. In: $5^{\text {th }}$ International Congress on Mechanisation and Energy Use in Agriculture. Turkey: Kusadasi; 11-14 October 1993. 
[16] Dutt, B. (1982). Comparative efficiency of energy use in rice production. Energy 1982; 6:25.

[17] Baruah, D. (1995). Utilisation pattern of human and fuel energy in the plantation. Journal of Agriculture and Soil Science 1995; 8(2): 189-92.

[18] Thakur, C. Mistra, B. (1993). Energy requirements and energy gaps for production of major crops in India. Agricultural Situation of India 1993; 48: 665-89.

[19] Wu, J. and Boggess, W. (1999). The optimal allocation of conservation funds. Journal Environmental Economic Management. 1999; 38.

[20] OECD/IEA. (2004). Renewables for power generation: status and prospect. UK, 2004.

[21] Duffie, J.A. and Beckman, W.A. (1980). Solar Engineering of Thermal Processes. New York: J. Wiley and Sons; 1980.

[22] Sivkov, S.I. (1964a). To the methods of computing possible radiation in Italy. Trans. Main Geophys. Obs. 1964; 160.

[23] Sivkov, S.I. (1964b). On the computation of the possible and relative duration of sunshine. Trans. Main Geophys Obs 160. 1964.

[24] Barabaro, S., Coppolino, S., Leone, C., and Sinagra, E. (1978). Global solar radiation in Italy. Solar Energy 1978; 20: 431-38.

[25] Hall, O. and Scrase, J. (1998). Will biomass be the environmentally friendly fuel of the future? Biomass and Bioenergy 1998: 15: 357-67.

[26] Pernille, M. (2004). Feature: Danish lessons on district heating. (2004). Energy Resource Sustainable Management and Environmental March/April 2004: 16-17.

[27] D'Apote, S.L. (1998). IEA biomass energy analysis and projections. In: Proceedings of Biomass Energy Conference: Data, analysis and Trends, Paris: OECD; 23-24 March 1998.

[28] Abdeen, M. Omer. (2008a). Energy, environment and sustainable development. Renewable and Sustainable Energy Reviews, 12, 2265-2300.

[29] Omer, A. M. (2008a). Energy demands for heating and cooling equipment systems and technology advancement. Natural Resources: Economics, Management and Policy, 131-165.

[30] Abdeen M. Omer. (2008b). Ground-source heat pumps systems and applications, Renewable and Sustainable Energy Reviews, Vol.12, No.2, p.344-371, United Kingdom, February 2008.

[31] Abdeen M. Omer. (2007). Review: Organic waste treatment for power production and energy supply, Journal of Cell and Animal Biology, Vol.1, No.2, p.034-047, Nigeria, October 2007.

[32] Omer, A. M. (2008c). Energy demand for heating and cooling equipment systems and technology advancements. In: Natural Resources: Economics, Management and Policy, p.131165.

[33] Abdeen M. Omer. (2008d). Green energies and the environment. Renewable and Sustainable Energy Reviews, 12: 1789-1821.

[34] Abdeen M. Omer. (2012a). Opportunities for sustainable low carbon energy research development and applications. Cooling India, 7 (10): 60-81.

[35] Abdeen M. Omer. (2012b). Biomass energy resources utilisation and waste management. Agricultural Science, 3 (1): 124-145.

[36] Rasslavicius L, Grzybek A, and Dubrovin V (2011). Bioenergy in Ukraine - possibilities of rural development and opportunities for local communities. Journal Energy Policy 201139 (6): 3370-3379.

[37] Guilherme AD, Luiz FL, and Legey AM (2013). Energy from sugarcane bagasse in Brazil: An assessment of the productivity and cost of different technological routes. Renewable and Sustainable Energy Reviews, 21: 356-364.

[38] Cihan G, Dursun B, Bora A, Erkan S (2009). Importance of biomass energy as alternative to other sources in Turkey, Energy Policy 37 (2) (2009) 424-431. 